\title{
Front Matter: Volume 9410
}

, "Front Matter: Volume 9410," Proc. SPIE 9410, Visual Information Processing and Communication VI, 941001 (16 March 2015); doi: $10.1117 / 12.2191392$

SPIE Event: SPIE/IS\&T Electronic Imaging, 2015, San Francisco, California, United SPIE. States 


\title{
Visual Information Processing and Communication VI
}

\author{
Amir Said \\ Onur G. Guleryuz \\ Robert L. Stevenson \\ Editors
}

10-12 February 2015

San Francisco, California, United States

Sponsored by

IS\&T-The Society for Imaging Science and Technology

SPIE

Published by

SPIE 
The papers included in this volume were part of the technical conference cited on the cover and title page. Papers were selected and subject to review by the editors and conference program committee. Some conference presentations may not be available for publication. The papers published in these proceedings reflect the work and thoughts of the authors and are published herein as submitted. The publishers are not responsible for the validity of the information or for any outcomes resulting from reliance thereon.

Please use the following format to cite material from this book:

Author(s), "Title of Paper," in Visual Information Processing and Communication VI, edited by Amir Said, Onur G. Guleryuz, Robert L. Stevenson, Proceedings of SPIE-IS\&T Electronic Imaging, SPIE Vol. 9410, Article CID Number (2015)

ISSN: 0277-786X

ISBN: 9781628415001

Copublished by

SPIE

P.O. Box 10, Bellingham, Washington 98227-0010 USA

Telephone +1 3606763290 (Pacific Time) • Fax +1 3606471445

SPIE.org

and

IS\&T-The Society for Imaging Science and Technology

7003 Kilworth Lane, Springfield, Virginia, 22151 USA

Telephone +1 7036429090 (Eastern Time) • Fax +1 7036429094

imaging.org

Copyright (C) 2015, Society of Photo-Optical Instrumentation Engineers and The Society for Imaging Science and Technology.

Copying of material in this book for internal or personal use, or for the internal or personal use of specific clients, beyond the fair use provisions granted by the U.S. Copyright Law is authorized by the publishers subject to payment of copying fees. The Transactional Reporting Service base fee for this volume is $\$ 18.00$ per article (or portion thereof), which should be paid directly to the Copyright Clearance Center (CCC), 222 Rosewood Drive, Danvers, MA 01923. Payment may also be made electronically through CCC Online at copyright.com. Other copying for republication, resale, advertising or promotion, or any form of systematic or multiple reproduction of any material in this book is prohibited except with permission in writing from the publisher. The CCC fee code is 0277-786X/15/\$18.00.

Printed in the United States of America.

Paper Numbering: Proceedings of SPIE follow an e-First publication model, with papers published first online and then in print. Papers are published as they are submitted and meet publication criteria. A unique citation identifier (CID) number is assigned to each article at the time of the first publication. Utilization of CIDs allows articles to be fully citable as soon as they are published online, and connects the same identifier to all online, print, and electronic versions of the publication. SPIE uses a six-digit CID article numbering system in which:

- The first four digits correspond to the SPIE volume number.

- The last two digits indicate publication order within the volume using a Base 36 numbering

system employing both numerals and letters. These two-number sets start with 00, 01, 02, 03, 04, $05,06,07,08,09,0 A, 0 B \ldots$ OZ, followed by 10-1Z, 20-2Z, etc.

The CID Number appears on each page of the manuscript. The complete citation is used on the first page, and an abbreviated version on subsequent pages. 


\title{
Contents
}

\author{
$\checkmark$ Authors \\ vii Conference Committee
}

\section{SESSION 1 IMAGE RESTORATION AND DEBLURRING}

941002 A new robust method for two-dimensional inverse filtering [9410-1]

941003 Semi-blind deblurring images captured with an electronic rolling shutter mechanism [9410-2]

941004 Video pre-processing with JND-based Gaussian filtering of superpixels [9410-7]

941005 Restoration of block-transform compressed images via homotopic regularized sparse reconstruction [9410-4]

941006 Rain detection and removal algorithm using motion-compensated non-local mean filter [9410-5]

$941007 \quad$ Exploiting perceptual redundancy in images [9410-6]

\section{SESSION 2 VIDEO COMPRESSION}

941008 Predicting chroma from luma with frequency domain intra prediction [9410-3]

941009 Perceptual vector quantization for video coding [9410-8]

9410 0A Adaptive residual DPCM for lossless intra coding [9410-9]

$9410 \mathrm{OB} \quad$ Arithmetic coding with constrained carry operations [9410-11]

9410 0C Adaptive motion compensation without blocking artifacts [9410-10]

\section{SESSION 3 VIDEO COMMUNICATIONS}

9410 OD Quality optimization of H.264/AVC video transmission over noisy environments using a sparse regression framework [9410-12]

9410 OE Game theoretic wireless resource allocation for H.264 MGS video transmission over cognitive radio networks [9410-13] 
$94100 \mathrm{~A}$ A novel framework for automatic trimap generation using the Gestalt laws of grouping [9410-16]

$9410 \mathrm{OH} \quad$ Efficient graph-cut tattoo segmentation [9410-17]

94100 Ol Contourlet transform based human object tracking [9410-18]

9410 0J Saliency-based artificial object detection for satellite images [9410-19]

9410 OK Quantitative analysis on lossy compression in remote sensing image classification [9410-20]

$9410 \mathrm{OL} \quad$ Image completion using image skimming [9410-21]

\section{INTERACTIVE PAPER SESSION}

$94100 \mathrm{M}$ A method for ultra-fast searching within traffic filtering tables in networking hardware [9410-15]

9410 ON Spatial resampling of IDR frames for low bitrate video coding with HEVC [9410-22]

941000 Speed-up keypoint mapping technique by multi-resolution and global information [9410-23]

9410 OP Building reliable keypoint matches by a cascade of classifiers with resurrection mechanism [9410-24]

$94100 Q \quad$ Automatic coloring to freehand line drawings online [9410-25]

9410 OR Frameless representation and manipulation of image data [9410-26] 


\section{Authors}

Numbers in the index correspond to the last two digits of the six-digit citation identifier (CID) article numbering system used in Proceedings of SPIE. The first four digits reflect the volume number. Base 36 numbering is employed for the last two digits and indicates the order of articles within the volume. Numbers start with 00, 01, 02, 03, 04, 05, 06, 07, 08, 09, 0A, 0B...0Z, followed by 10-1Z, 20-2Z, etc.

Agrafiotis, Dimitris, ON

Al-Kabbany, Ahmad, OG, OL

Blekas, K., OD

Bull, David, ON

Cai, Xun, OA

Chen, Zhenzhong, 07, 0J, OK

Clausi, David A., 05

Delp, Edward J., $\mathrm{OH}$

Dietz, Henry Gordon, OR

Ding, Lei, 04

Ding, Xiaoying, OJ

Dubois, Eric, OG, OL

Easton, Nick, ON

Egge, Nathan E., 08

Fan, Chunxiao, OP

Fang, Yuming, $0 \mathrm{~J}$

Fragkoulis, Alexandros, $\mathrm{OE}$

Frantc, Vladimir A., OM

Fuller, Megan M., 02

Glaister, Jeffrey, 05

Haider, Shahid A., 05

Hosking, Brett, ON

Jin, Hongbin, OO, OP

Jing, Jing, OP

$\mathrm{Ke}$, Shidong, OJ

Khare, Ashish, 01

Khare, Manish, 01

Kim, Joonsoo, $\mathrm{OH}$

Kondi, Lisimachos P., OD, OE

Kumar, S., OD

Kurata, Saori, $0 Q$

$\mathrm{Li}, \mathrm{Ge}, 04$

$\mathrm{Li}, \mathrm{He}, \mathrm{OH}$

Li, Yong, OO, OP

$\mathrm{Li}$, Zimeng, OK

Lim, Jae S., 02, OA

Liu, Hongyi, 07

Mahfoodh, Abo-Talib, OB

Makov, Sergey V., OM

Marchuk, Vladimir I., OM

Mori, Hiroshi, $O Q$

Obukhovets, Victor A., OM

Paluri, S., OD

Pandremmenou, K., OD

Parra, Albert, $\mathrm{OH}$

Parsopoulos, Konstantinos E., OE

Prakash, Om, Ol

Qiao, Wei, 00, OP

Said, Amir, OB
Seo, S. J., 06

Shoji, Kenji, OQ

Song, B. C., 06

Srivastava, Rajneesh Kumar, 01

Stevenson, Robert L., 03

Terriberry, Timothy B., 09, 0C

Toyama, Fubito, $0 Q$

Tziortziotis, N., OD

Valin, Jean-Marc, 08, 09

Voronin, Viacheslav $\mathrm{V}$., OM

Wang, Ronggang, 04

Wang, Wenmin, 04

Wen, Zhigang, 00

Wong, Alexander, 05

Xia, Yatong, OK

Yang, Daiqin, OJ, OK

Yea, Sehoon, OB

Zhang, W., OD

Zhen, Ruiwen, 03 
SPIE-IS\&T/ Vol. $9410941001-6$

Downloaded From: https://www.spiedigitallibrary.org/conference-proceedings-of-spie on 26 Apr 2023 Terms of Use: https://www.spiedigitallibrary.org/terms-of-use 


\section{Conference Committee}

Symposium Chair

Sheila S. Hemami, Northeastern University (United States)

Symposium Co-chair

Choon-Woo Kim, Inha University (Korea, Republic of)

Conference Chairs

Amir Said, LG Electronics MobileComm U.S.A., Inc. (United States)

Onur G. Guleryuz, LG Electronics MobileComm U.S.A., Inc.

(United States)

Robert L. Stevenson, University of Notre Dame (United States)

Conference Program Committee

John G. Apostolopoulos, Hewlett-Packard Laboratories

(United States)

Vasudev Bhaskaran, Qualcomm Inc. (United States)

Mireille Boutin, Purdue University (United States)

Chang Wen Chen, University at Buffalo (United States)

Gerard de Haan, Philips Research Nederland B.V. (Netherlands)

Edward J. Delp III, Purdue University (United States)

Eric Dubois, University of Ottawa (Canada)

Frederic Dufaux, Télécom ParisTech (France)

Keigo Hirakawa, University of Dayton (United States)

Marta Karczewicz, Qualcomm Inc. (United States)

Lisimachos P. Kondi, University of loannina (Greece)

Janusz Konrad, Boston University (United States)

Chun-Chieh J. Kuo, The University of Southern California

(United States)

Peyman Milanfar, University of California, Santa Cruz (United States)

Antonio Ortega, The University of Southern California (United States)

Thrasyvoulos N. Pappas, Northwestern University (United States)

William A. Pearlman, Rensselaer Polytechnic Institute (United States)

Fernando Pereira, Instituto de Telecomunicações (Portugal)

Béatrice Pesquet-Popescu, Télécom ParisTech (France)

Majid Rabbani, Eastman Kodak Company (United States)

Eli Saber, Rochester Institute of Technology (United States)

Dan Schonfeld, University of Illinois at Chicago (United States)

Andrew Segall, Sharp Laboratories of America, Inc. (United States)

Gaurav Sharma, University of Rochester (United States) 
Andrew G. Tescher, AGT Associates (United States)

Anthony Vetro, Mitsubishi Electric Research Laboratories (United States)

John W. Woods, Rensselaer Polytechnic Institute (United States)

Wenwu Zhu, Tsinghua University (China)

\section{Session Chairs}

$1 \quad$ Image Restoration and Deblurring

Robert L. Stevenson, University of Notre Dame (United States)

2 Video Compression

Amir Said, LG Electronics MobileComm U.S.A., Inc. (United States)

Onur G. Guleryuz, LG Electronics MobileComm U.S.A., Inc.

(United States)

3 Video Communications

Amir Said, LG Electronics MobileComm U.S.A., Inc. (United States)

Onur G. Guleryuz, LG Electronics MobileComm U.S.A., Inc.

(United States)

4 Image Recognition and Segmentation

Robert L. Stevenson, University of Notre Dame (United States) 